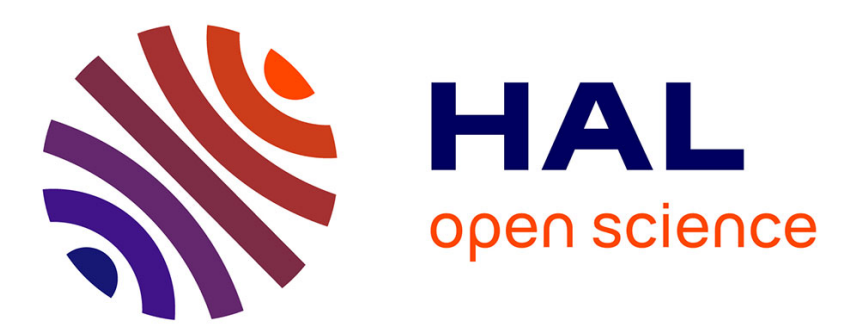

\title{
Myostatin inhibits proliferation but not differentiation of trout myoblasts
}

Iban Seiliez, Nathalie Sabin, Jean-Charles Gabillard

\section{To cite this version:}

Iban Seiliez, Nathalie Sabin, Jean-Charles Gabillard. Myostatin inhibits proliferation but not differentiation of trout myoblasts. Molecular and Cellular Endocrinology, 2012, 351 (2), pp.220-226. 10.1016/j.mce.2011.12.011 . hal-01205050

\section{HAL Id: hal-01205050 \\ https://hal.science/hal-01205050}

Submitted on 29 May 2020

HAL is a multi-disciplinary open access archive for the deposit and dissemination of scientific research documents, whether they are published or not. The documents may come from teaching and research institutions in France or abroad, or from public or private research centers.
L'archive ouverte pluridisciplinaire HAL, est destinée au dépôt et à la diffusion de documents scientifiques de niveau recherche, publiés ou non, émanant des établissements d'enseignement et de recherche français ou étrangers, des laboratoires publics ou privés. 
Version définitive du manuscrit publié dans / Final version of the manuscript published in : Molecular and Cellular Endocrinology 2012, 351 (2) : 220-226

1 Myostatin inhibits proliferation but not differentiation of trout myoblasts

2

3

4 Seiliez Iban $^{2}$, Sabin Nathalie ${ }^{1}$, Gabillard Jean-Charles ${ }^{1 *}$

5

6

${ }^{1}$ INRA, UR1037 Laboratoire de Physiologie et Génomique des Poissons, Equipe Croissance et

7 Qualité de la Chair de Poisson, Campus de Beaulieu, 35000 Rennes, France.

2 INRA, UMR1067 Nutrition Métabolisme et Aquaculture, Pôle d'hydrobiologie, CD918, F-64310

9 St-Pée-sur-Nivelle, France.

10

11

12

13

14

15 Keywords: MyoD, Myogenin, myosin, IGF1, fish, muscle, Smad,

16

$17 *$ Corresponding author:

18 Dr Jean-Charles Gabillard : Jean-Charles.Gabillard@ rennes.inra.fr

19 INRA, UR1037 Laboratoire de Physiologie et Génomique des Poissons, Equipe Croissance et Qualité de la

20 Chair de Poisson, Campus de Beaulieu, 35000 Rennes, France.

21 Tel: +33223485016

22 Fax: +33223485002

23 


\section{ABSTRACT}

26 The muscle growth in mammals is regulated by several growth factors including myostatin 27 (MSTN), a member of the transforming growth factor-beta (TGF-beta) superfamilly. To date, it is 28 unknown in fish whether MSTN could have any effect on proliferation or differentiation of 29 myogenic cells. Using culture of trout satellite cells, we showed that mstnla and mstnlb mRNA are 30 expressed in myoblasts and that their expression decreased in differentiating myoblasts. We also 31 demonstrated that a treatment with huMSTN decreased the proliferation of IGF1-stimulated 32 myoblasts in a dose-dependent manner. By contrast, treatment of myoblasts with $100 \mathrm{nM}$ of 33 huMSTN for 3 days, did not affect the percentage of positive cells for myogenin neither the 34 percentage of nuclei in myosin positive cells. Moreover, our results clearly indicated that huMSTN 35 treatment had no effect on MyoD and Myogenin protein levels, which suggests that huMSTN did 36 not strongly affect MyoD activity.

37 In conclusion, we showed that huMSTN inhibited proliferation but not differentiation of trout 38 myoblasts, probably resulting from a lack of huMSTN effect on MyoD activity. Altogether, these 39 results show high interspecies differences in the function of MSTN. 
published in : Molecular and Cellular Endocrinology 2012, 351 (2) : 220-226

\section{INTRODUCTION}

41

42 By contrast to the mammals and model fish species (zebrafish, medaka), salmonids such as trout 43 exhibit an indeterminate muscle growth pattern, with muscle mass increasing until mortality or 44 senescence occurs (Johnston 1999; Mommsen 2001). This increase in myotomal muscle mass 45 throughout their life cycle is allowed by a continuous production of muscle fibers (hyperplasia) in 46 addition to an increase of fibers size (hypertrophy). However, the molecular mechanisms involved 47 in these interspecies differences are complex and not well understood.

48 In mammals, muscle growth is regulated by several growth factors including myostatin (MSTN), a 49 member of the transforming growth factor-beta (TGF-beta) superfamilly. The mstn gene, expressed mostly in skeletal muscle, was first identified in mice by McPherron et al., (1997) and has been

51 demonstrated to negatively regulate skeletal muscle growth in several mammalian species. The

52 knockout of mstn or the overexpression of follistatin, its endogenous inhibitor, induces a dramatic 53 increase of muscle mass, resulting from a combination of hyperplasia and hypertrophy (McPherron 54 et al., 1997; Lee and McPherron 2001). MSTN acts through its binding to the activin type II 55 receptor which in turn binds to and activates the activin receptor type I that phosphorylates the 56 transcription factors Smad2 and Smad3 (Lee and McPherron 2001; Zhu et al., 2004). In vitro 57 studies demonstrated that MSTN inhibits the proliferation and the differentiation of myogenic cells 58 (Thomas et al., 2000; Ríos et al., 2001; Langley et al., 2002). The inhibition of differentiation is 59 accomplished by decreasing the level of MyoD protein as well as its activity (Langley et al., 2002). 60 Indeed, it has been shown that TGF-beta inhibits MyoD activity through a physical interaction 61 between MyoD and Smad3 (Liu et al., 2001).

62 In fish, the mstn cDNA has been cloned in numerous species such as trout (Rescan et al., 2001; 63 Roberts and Goetz 2001; Garikipati et al., 2006; Garikipati et al., 2007), zebrafish (Xu et al., 2003; 64 Kerr et al., 2005), medaka (Sawatari et al., 2010), tilapia (Rodgers et al., 2001), white bass (Rodgers 
POS\{

Version définitive du manuscrit publié dans / Final version of the manuscript

published in : Molecular and Cellular Endocrinology 2012, 351 (2) : 220-226

65 et al., 2001), striped bass (Rodgers and Weber 2001), white perch (Rodgers and Weber 2001), sea

66 bass (Terova et al., 2006), Orange spotted grouper (Ko et al., 2007) and sea bream (Funkenstein and

67 Rebhan 2007). As a result of the recent genome duplication in salmonids (Brunelli et al., 2001), four

68 distinct $m s t n$ genes ( $m \sin 1 a, m \operatorname{stn} 1 b, m \operatorname{stn} 2 a, m s t n 2 b)$ were found in trout (Garikipati et al., 2006;

69 Garikipati et al., 2007). Nevertheless, only mstnla and mstnlb are readily detectable in white

70 muscle since $m \operatorname{stn} 2 a$ muscle expression is 20 -fold lower. In contrast to what is observed in

71 mammals, mstn genes are expressed in most teleost fish tissues (Garikipati et al., 2006).

72 Comparison of MSTN sequences indicates that bioactive MSTN sequence is extremely well

73 conserved throughout evolution. In fact, trout MSTN sequence is $90 \%$ identical to human MSTN

74 (Garikipati et al., 2006). Several attempts have been made to elucidate the function of MSTN in fish

75 by decreasing MSTN activity but the result are somewhat divergent between species and even

within species. Injection of morpholinos in zebrafish embryos increases the number and size of

77 somites (Amali et al., 2004) as well as the expression of the regulatory factor MyoD and myogenin.

78 The overexpression of the prodomain of MSTN (a negative regulator of the active protein) fails to

79 increase the muscle mass of zebrafish and induces a moderate increase (10\%) of the fiber number

80 (Xu et al., 2003). Similarly, the overexpression of a dominant negative form of MSTN does not

81 have any strong consequences for medaka muscle mass (Sawatari et al., 2010). However, a recent

82 study in zebrafish carrying a stable heritable myostatin knockdown genotype, reports a "double-

83 muscled" phenotype (Lee et al., 2009). In trout, the overexpression of follistatin, an inhibitor of the

84 TGF-beta family member, induces an increase of muscle mass (Medeiros et al., 2009), but it

85 remains to be established whether the effect is due to solely myostatin inhibition or to another TGF-

86 beta inhibition. Despite these in vivo data, the function of MSTN in fish remains elusive.

87 Therefore, in order to gain deeper insight into the function of MSTN in fish, we aimed at 88 determining whether MSTN inhibits the proliferation and the differentiation of myogenic cells, 89 using an in vitro system of trout satellite cells culture. 


\section{MATERIALS AND METHODS}

\section{Animals}

93 Rainbow trout were maintained at the "Station Commune de Recherches en

94 Ichtyophysiologie, Biodiversité et Environnement" (SCRIBE, Rennes, France) in 0.6-m³

95 tanks in a re-circulated system at $18^{\circ} \mathrm{C}$. All experiments were carried out in accordance with

96 legislation governing the ethical treatment of animals (Decret $\mathrm{N}^{\circ}$ 2001-464, May 29, 2001),

97 and investigators were certified by the French Government to carry out animal experiments

98 ( $\mathrm{N}^{\circ}$ agrément 35-47). All animal work was approved by the Ministère de l'Enseignement

99 Supérieur et de le Recherche (Autorisation $\mathrm{N}^{\circ} \mathrm{A} 352386$ ).

100

101 Chemicals

102 Dulbecco's modified Eagle's medium (DMEM\#D7777) and F10 (\#N6635) were purchased 103 from SIGMA. Anti-MyoD (\#NB100-80899) antibody was purchased from Novus Biological, 104 anti-Myogenin (\#SC-567) from Santa-Cruz Biotechnology, anti-P-Smad3 (Ser ${ }^{423 / 425}$ ) from 105 Cell Signalling (\#9520), anti-Smad7 from Abgent (\#AP6753b). For immunofluorescence 106 analysis, the secondary antibody anti-mouse Alexa488 (\#A21441) and anti-rabbit Alexa594 107 (\#A11001) were purchased from Invitrogen. Recombinant trout IGF1 (\#WU100) was 108 purchased from GroPep and recombinant human MSTN (CYT-418) was purchased from 109 ProSpec and the specific inhibitor of Activin Receptor-Like kinases SB431542 (Inman et al., 110 2002) from SIGMA (\#S4317).

112 Satellite cells isolation and culture

113 Primary cultures of skeletal muscle cells were carried out as follows: for each culture, 30 to 60 114 animals, each weighing approximately $5 \mathrm{~g}$, were killed by a blow to the head and then 
115 immersed for $30 \mathrm{~s}$ in $70 \%$ ethanol to sterilize external surfaces. Cells were isolated, pooled,

116 and cultured following previously described protocols (Gabillard et al., 2010). Briefly, after

117 removal of the skin, dorsal white muscle was isolated under sterile conditions and collected in

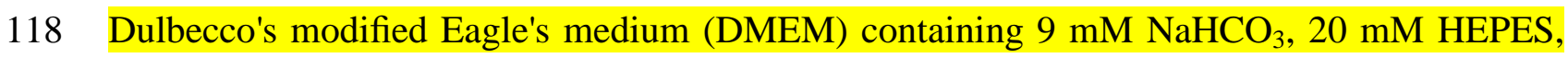

$11915 \%$ horse serum, and antibiotic-antimycotic cocktail $(100 \mathrm{U} / \mathrm{ml}$ penicillin, $100 \mu \mathrm{g} / \mathrm{ml}$

120 streptomycin, $0.25 \mathrm{~g} / \mathrm{ml}$ fungizone) at $\mathrm{pH}$ 7.4. After mechanical dissociation of the muscle in

121 small pieces, the tissue was enzymatically digested with a $0.2 \%$ collagenase solution in

122 DMEM for $1 \mathrm{~h}$ at $18^{\circ} \mathrm{C}$ and gentle shaking. The suspension was centrifuged $(300 \mathrm{~g}$ for $5 \mathrm{~min}$

123 at $15^{\circ} \mathrm{C}$ ) and the resulting pellet was subjected to two rounds of enzymatic digestion with a

$1240.1 \%$ trypsin solution in DMEM for 20 min at $18^{\circ} \mathrm{C}$ with gentle agitation. After each round of

125 trypsinization the suspension was centrifuged and the supernatant was diluted in 2 volumes of

126 cold DMEM supplemented with $15 \%$ horse serum and the same antibiotic-antimycotic

127 cocktail mentioned above. After two washes with DMEM, the cellular suspension was filtered

128 through $100-$ and $40-\mu \mathrm{m}$ nylon filters. All experiments were conducted with cells seeded at a

129 density of $160000 / \mathrm{cm}^{2}$, in six-wells or 24-wells plastic plates (Nunc, Roskilde, Denmark) and

130 left for 30 min before medium change. Plates and coverslips were previously treated with

131 poly-L-lysine and laminin to facilitate satellite cells adhesion. Cells were incubated at $18^{\circ} \mathrm{C}$,

132 the optimal temperature for culture, with DMEM or F10 containing $9 \mathrm{mM} \mathrm{NaHCO} 3,20 \mathrm{mM}$

133 HEPES, 10\% fetal bovine serum, and antibiotic-antimycotic cocktail under an air atmosphere.

134 According to the experiments, the cells were cultivated in proliferating medium

$135(\mathrm{~F} 10+10 \% \mathrm{FCS})$ or differentiating medium (DMEM+2\%FCS). The medium was renewed

136 every 2 days and observations of morphology were regularly made to control the state of the

137 cells. 


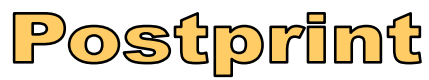

Version définitive du manuscrit publié dans / Final version of the manuscript published in : Molecular and Cellular Endocrinology 2012, 351 (2) : 220-226

139 Gene expression analysis

140 The medium was removed, and wells were washed twice with PBS. The cells were lysed with

141 the lysis buffer of the Nucleospin RNA XS kit (Macherey-Nagel, \#N0740-902-50) and total

142 RNA were extracted according to the manufacturer's recommendations. The total amount of

143 RNA was determined as a function of absorbance at $260 \mathrm{~nm}$ (Nanodrop ND-1000

144 spectrophotometer). The cDNA was generated with $0.5 \mu \mathrm{g}$ total RNA using a commercial kit 145 (Applied Biosystems, \#4368813). Briefly, $0.5 \mu \mathrm{g}$ of total RNA was incubated in a $25 \mu \mathrm{l}$ 146 mixture (10x RT buffer, 25x dNTPs, 10x random primers, 50UI/ $\mu$ l MultiScribe ${ }^{\mathrm{TM}}$ Reverse

147 Transcriptase, nuclease-free water) at $25^{\circ} \mathrm{C}$ for $10 \mathrm{~min}$ and then at $37^{\circ} \mathrm{C}$ for $120 \mathrm{~min}$. The 148 reaction was set at $200 \mu 1$ by the addition of nuclease-free water. Target gene expression levels 149 were determined by quantitative RT-PCR using a StepOnePlus system (Applied Biosystems). 150 Analyses were carried out using a real-time PCR kit (Fast SyberGreen Master mix, \#4385612 151 - Applied Biosystems) with $300 \mathrm{nM}$ of each primer. The primer sequences (Table 1) for 152 mstnla, mstnlb and elongation factor $1 \alpha(e F 1 \alpha)$ were already published and validated 153 (Seiliez et al., 2011). All the primers span exon-bondaries to prevent genomic DNA 154 amplification. Amplification was then performed using the following cycle: $95^{\circ} \mathrm{C}$ for $3 \mathrm{~s}$, $15560^{\circ} \mathrm{C}$ for $15 \mathrm{~s}, 40$ times for all primers. The melting curves systematically monitored at the 156 end of the last amplification cycle, show one peak which confirm the specificity of the 157 amplification reaction. Each PCR run included replicate samples (duplicate of reverse 158 transcription and PCR amplification). Relative quantity (Arbitrary unit, A.U.) was determined 159 from a standard curve consisting of a serial dilutions of a pool of cDNA. The efficiencies 160 obtained with the primers pairs ranged from 85 to $100 \%$. EF1 $\alpha$ mRNA abundance was not 161 significantly affected by the treatments and was thus used for the normalization of qPCR data. 


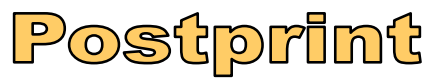

Version définitive du manuscrit publié dans / Final version of the manuscript published in : Molecular and Cellular Endocrinology 2012, 351 (2) : 220-226

163 Protein extraction and Western blotting

164 After two washes with cold PBS, proteins were extracted with RIPA Buffer (50 mM Tris pH8, $1651 \mathrm{mM}$ EDTA, $0.5 \mathrm{mM}$ EGTA, $1 \%$ NP-40, 0.5\% Sodium deoxyclolate, $0.1 \%$ SDS, $150 \mathrm{mM}$ $166 \mathrm{NaCl}$ ) supplemented with $5 \mathrm{mM} \mathrm{NaF}, 1 \mathrm{mM} \mathrm{NaVO} 4$ and protease inhibitors cocktail (Roche). 167 Laemmli Buffer was added to the sample and heated at $90^{\circ} \mathrm{C}$ for $5 \mathrm{~min}$. Cell lysates were 168 subjected to SDS-PAGE and Western blotting using the appropriate antibody. Antibody 169 against MyoD and myogenin have been previously validated in trout (Gabillard et al., 2010). 170 The antibody against P-Smad3 $\left(\operatorname{Ser}^{423 / 425}\right)$ recognize the human amino acid sequence around $171 \operatorname{Ser}^{423 / 425}$ that is very well conserved in trout (MGSPS / $\mathrm{RCSS}_{\mathrm{V}}^{\mathrm{V}} \mathrm{M}$ ). Similarly, the antibody 172 against Smad7 recognize the sequence between 362 392 aa that is very well conserved in

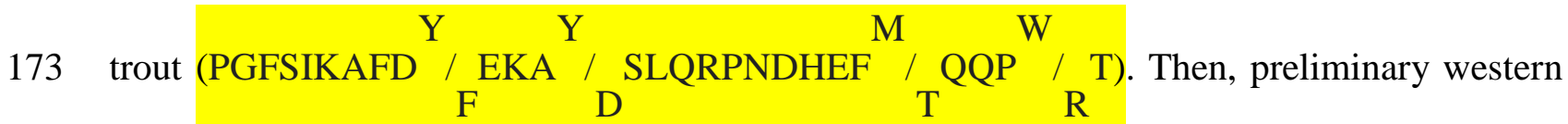
174 blot with the anti-P-Smad3 and Anti-Smad7 antibodies were performed with lysates from 175 murine $\mathrm{C} 2 \mathrm{C} 12$ cell line and from trout. With trout satellite cells lysate, we obtained a single 176 band for each antibody (P-Smad3 : 55-60 kDa; Smad7 : 45-50 kDa) with the same size as that 177 of C2C12 (data not shown). After washing, the membrane was incubated $1 \mathrm{~h}$ with secondary 178 antibody (1/15000) linked to HRP (Jackson Immunoresearch). Immunoreactive bands were 179 visualized by ECL and images were obtained with an image acquisition system (Fusion FX7, 180 Vilbert Lourmat).

\section{Immunofluorescence analysis}

183 Cells on glass coverslips were briefly washed twice with PBS and fixed 10 min with 184 paraformaldehyde 4\%. For permeabilization, cells were incubated $3 \mathrm{~min}$ in $0.1 \%$ 185 TritonX100/PBS. After three washes, cells were saturated for $1 \mathrm{~h}$ with $3 \%$ BSA, $0.1 \%$ 186 Tween20 in PBS (PBST). Cells were incubated $3 \mathrm{~h}$ with the primary antibodies anti-myosin 
187 and anti-myogenin diluted in blocking buffer. The secondary antibodies were diluted in PBST

188 and applied for $1 \mathrm{~h}$. Cells were mounted with Mowiol 4-88 (\#475904, Calbiochem)

189 containing Hoescht $(0.5 \mu \mathrm{g} / \mathrm{ml})$. Cells were photographed using a Canon digital camera

190 coupled to a Canon 90i microscope.

192 Analysis of cell proliferation

193 The mature myostatin protein is extremely well conserved between fish and mammals and 194 trout MSTN is 90\% identical to human MSTN (Rescan et al., 2001; Garikipati et al., 2006). 195 Thus, we used recombinant human MSTN (\#CYT-418, ProSpec) in our experiments. From 196 the day of extraction, the cells were incubated in F10 (+10\% FCS) medium. At day 1, cells 197 were cultivated in F10 alone, and at day 2 cells were cultivated in F10+2\%FCS and 198 recombinant trout IGF1 $(50 \mathrm{nM})$ and human $\operatorname{MSTN}(0.1,1$ or $10 \mathrm{nM})$ were added. At day 3, 199 BrdU was added for the following $24 \mathrm{~h}$. The cells were fixed with ethanol/glycine buffer 200 (70\% ethanol, $50 \mathrm{mM}$ glycine, $\mathrm{pH}$ 2). The proliferation of the cells was measured by using the 201 BrdU labeling and detection kit (Roche Diagnostics, no. 1296 736). Briefly, the cells were 202 incubated for $30 \mathrm{~min}$ at $37^{\circ} \mathrm{C}$ with mouse anti-BrdU, washed, and then incubated with the 203 secondary antibody anti-mouse FITC. Cells were mounted in Mowiol containing $0.5 \mu \mathrm{g} / \mathrm{ml}$ 204 DAPI.

205 Statistical analysis

206 Results are presented as means \pm SD. Treatment effect was assessed using the non-parametric 207 Kruskall-Wallis ANOVA (Statistica 7.0, StatSoft). When ANOVA revealed significant effect 208 Mann-Whitney test was performed. All the experiments were performed at least 2 times. 


\section{RESULTS}

\section{Mstnla and mstnlb gene expression decreases during in vitro differentiation of trout}

\section{2 myoblasts}

213 We monitored the expression of mstnla and mstnlb genes by quantitative PCR during

214 proliferation and differentiation of myoblasts. Our results (Figure 1) showed that mstnla and $215 m \min 1 b$ were expressed in myoblasts. During the first week of culture in proliferation 216 medium, no significant change of mstnla and mstnlb mRNA levels was observed. By 217 contrast, as soon as 2 days after induction of differentiation (DM2), mstn $1 a$ and mstnlb 218 mRNA levels significantly decreased ( 4-fold). After 4 days in differentiation medium 219 (DM4), the levels of mstn1a and $m \operatorname{stn} 1 b$ were similar to that of observed at DM2. These 220 results indicated that both mstn genes were regulated during the proliferation and the 221 differentiation phases suggesting a role of MSTN on trout myoblast proliferation and (or) 222 differentiation.

\section{HuMSTN activates Smad3 phosphorylation in myoblasts and myotubes of trout}

225 Sequence analysis showed that the sequences of trout myostatins were very similar to that of 226 human (90\%) as previously reported (Rescan et al., 2001; Garikipati et al., 2006). To validate 227 the use of heterologous myostatin in our in vitro system, we monitored the activity of 228 recombinant human MSTN (HuMSTN) by measuring the phosphorylation status of Smad3 a 229 key factor in the MSTN signaling pathway (Sartori et al., 2009). As shown in figure 2A and $2302 \mathrm{~B}$, the stimulation of both trout myoblasts and myotubes with $100 \mathrm{nM}$ of huMSTN for $1 \mathrm{~h}$ 231 induced the phosphorylation of Smad3. Furthermore, to demonstrate the specificity of this 232 hormonal response, we used a chemical inhibitor (SB431542) specific to the activin receptor 233 type I (ActRI) known to transduce MSTN signal (Lee et al., 2005; Miyake et al., 2010). The 


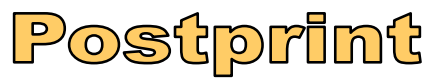

Version définitive du manuscrit publié dans / Final version of the manuscript published in : Molecular and Cellular Endocrinology 2012, 351 (2) : 220-226

234 treatment of the cells with this chemical inhibitor completely abolished the huMSTN-induced

235 phosphorylation of Smad3 in myoblasts as well as in myotubes (Figure 2A and 2B). Therefore

236 the huMSTN specifically phosphorylated Smad3 through the activation of the ActRI as

237 expected and our results showed that trout myoblasts and myotubes were able to transduce the

238 huMSTN signal.

240 HuMSTN inhibits proliferation of myoblasts in vitro

241 To determine whether huMSTN inhibits the proliferation of myoblasts, we treated the cells

242 with huMSTN during $48 \mathrm{~h}$ and monitored the cell proliferation by mean of the BrdU

243 incorporation technique (Gabillard et al., 2010). To limit the putative non-specific effect of the

244 serum, we cultivated the cells in F10 with only $2 \%$ of fetal calf serum (FCS). Under these

245 conditions the basal level of proliferation was low $(\sim 10 \%)$ and huMSTN treatment had no

246 effect on proliferation whatever the doses $(0.1$ to $10 \mathrm{nM})$ (Figure 3). Then, to increase the

247 proliferation, we treated the cells with $50 \mathrm{nM}$ recombinant trout IGF1 (rtIGF1) given that it

248 has been shown to stimulate the proliferation of myoblasts (Gabillard et al., 2010). Under

249 these conditions, rtIGF1 treatment strongly stimulated proliferation (10\% versus 60\%) and we

250 observed a dose-dependent decrease of proliferation in presence of increasing doses of

251 huMSTN (Figure 3). These results clearly showed that huMSTN was able to decrease the

252 proliferation of trout myoblasts.

254 HuMSTN has no effect on the differentiation of trout myoblasts

255 In order to determine whether huMSTN inhibited the differentiation of myoblasts, we treated

256 the cells with huMSTN during the induction of differentiation. The differentiation index ( $\%$ of

257 nuclei in myosin or myogenin positive cells) was determined by immunofluorescence

258 analysis. Preliminary experiments indicated that low doses of huMSTN $(0.5,5,50 \mathrm{nM})$ did 

published in : Molecular and Cellular Endocrinology 2012, 351 (2) : 220-226

not have an effect (data not shown). Therefore, a higher dose of huMSTN was tested (100

$\mathrm{nM}$ ) that is within the range previously reported (Langley et al., 2002). Our results (Figure 4A

and 4B) showed that after 3 days in the differentiation medium (DMEM+2\%FCS), myoblasts

were clearly differentiated into myotubes. Indeed after 3 days in differentiating medium, the percentage of nuclei in myosin positive cells (1\% versus $23 \%)$ and the percentage of 264 myogenin positive nuclei increased (20\% versus 39\%). Moreover, treatment of the cells with $100 \mathrm{nM}$ huMSTN (Figure 4A and 4B) did not significantly affect the differentiation of myogenic cells (23\% versus $20 \%$ of nuclei in myosin positive cells) and (39\% versus $37 \%$ of myogenin positive nuclei). Altogether, these results showed that huMSTN treatment did not inhibit differentiation of trout myoblasts in vitro.

270 HuMSTN has no effect on the level of MyoD protein

271 It has been shown in mammals, that MSTN inhibits differentiation by decreasing MyoD 272 protein level as well as MyoD activity (Langley et al., 2002). Our results (Figure 5) showed 273 that huMSTN treatment during $48 \mathrm{~h}$ increased the amount of Smad7, a protein known to be 274 responsive to TGFb treatment Zhao et al., (2000). Surprisingly, huMSTN did not affect MyoD 275 protein level in our cell culture model (Figure 5). Because MSTN inhibits also MyoD activity, 276 we measured the protein level of myogenin which function downstream of MyoD as a key 277 regulator of myoblast differentiation. Again western blot analysis clearly showed that 278 huMSTN treatment had no effect on myogenin protein level (Figure 5). Altogether, these 279 results indicated that treatment of trout muscle cells with huMSTN did not affect MyoD 280 activity. 


\section{DISCUSSION}

283 In mammals, MSTN belongs to the TGF-beta familly and is well known as a potent inhibitor 284 of the muscle growth (McPherron et al., 1997; Lee and McPherron 2001). Indeed, it has been 285 shown that MSTN inhibits both proliferation and differentiation of mammalian myogenic 286 cells (Thomas et al., 2000; Langley et al., 2002; Joulia et al., 2003; Trendelenburg et al., 287 2009). In fish, several works report an increase of muscle mass after decreasing MSTN 288 activity (Lee et al., 2009; Medeiros et al., 2009), while others failed to observe a strong (if 289 any) effect on muscle mass (Amali et al., 2004; Acosta et al., 2005; Sawatari et al., 2010). To 290 date, it is unknown in fish whether MSTN could have any effect on proliferation or 291 differentiation of myogenic cells. Therefore, the purpose of the present work was to determine 292 whether MSTN can affect the proliferation and the differentiation using an in vitro system of 293 trout satellite cells culture.

294 As a first step, we measured the expression of both mstnla and mstnlb during the 295 differentiation of myoblasts. In agreement with our previous study (Seiliez et al., 2011), we 296 showed that mstnla and mstnlb genes were expressed in trout myoblasts and myotubes. This 297 result is in accordance with the published data showing that mstnla and mstnlb were 298 expressed in muscle of rainbow trout (Rescan et al., 2001; Garikipati et al., 2006). 299 Furthermore, our results demonstrate that the expression of mstnla and mstn $1 b$ genes 300 decreased during the differentiation of myoblasts. This result contrasts with the observations 301 made in higher vertebrates where mstn gene expression increases during the differentiation of 302 myogenic cells (Ríos et al., 2001; Kocamis and Killefer 2002; Artaza et al., 2005; McFarland 303 et al., 2006; Theil et al., 2006; McFarland et al., 2007). This observation shows that the 304 regulation of mstn genes in a lower vertebrate such as the rainbow trout is different than in 305 higher vertebrates. Indeed, in mammals $m s t n$ is expressed nearly exclusively in skeletal 306 muscle whereas in fish mstn mRNA have been detected in a wide range of tissues (Rescan et 


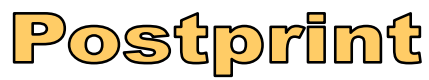

Version définitive du manuscrit publié dans / Final version of the manuscript published in : Molecular and Cellular Endocrinology 2012, 351 (2) : 220-226

307 al., 2001; Rodgers et al., 2001; Garikipati et al., 2006). Moreover, we recently demonstrated

308 that contrary to mouse $m s t n$ gene, trout $m s t n$ genes were not regulated by FoxO1 transcription

309 factor (Seiliez et al., 2011). Altogether, these results show that at least in trout, the MSTN

310 protein is present in different tissues and at different cellular process than in mammals, which

311 may suggest that endogenous MSTN protein may have a different function in fish than in

312 mammals.

313 In an attempt to elucidate the function of MSTN in trout, we determined whether recombinant

314 human MSTN can inhibit the proliferation of trout myoblasts. When the cells were cultivated

315 with only $2 \%$ of FCS, the basal level of proliferation is too low to observe any inhibitory

316 effect of huMSTN. However, under IGF1 stimulation, we were able to observe an inhibitory

317 effect of huMSTN on the proliferation of myoblasts in good agreement with published data

318 obtained with mammalian (Thomas et al., 2000; Joulia et al., 2003) and avian (McFarland et

319 al., 2006; McFarland et al., 2007) models. Altogether, this result shows that endogenous trout

320 MSTN could inhibit the proliferation of myoblasts in vivo.

321 MSTN has been shown in mammals to inhibit not only the proliferation but also the 322 differentiation of myogenic cells in vitro (Langley et al., 2002; Joulia et al., 2003; 323 Trendelenburg et al., 2009). Using our in vitro system of satellite cells culture, we showed for 324 the first time in fish that huMSTN failed to inhibit the differentiation of the myogenic cells in 325 contrast to what is observed in mammals. This may explain the decrease of mstnla and $326 m s t n 1 b$ gene expressions observed during the differentiation of trout myoblasts, and supports 327 the hypothesis that endogenous MSTN has no effect on trout myoblast differentiation.

328 The MSTN action is mediated first by its binding to the activin type II receptors (ActRIIB and 329 ActRIIA) resulting in the phosphorylation of Smad2 and Smad3 (Lee and McPherron 2001; 330 Zhu et al., 2004). Our results clearly showed that huMSTN stimulation induced a specific 331 phosphorylation of Smad3 both in myotubes and myoblasts. Moreover, the phosphorylation of 


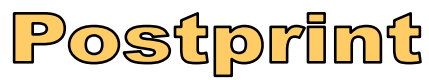

Version définitive du manuscrit publié dans / Final version of the manuscript published in : Molecular and Cellular Endocrinology 2012, 351 (2) : 220-226

332 Smad3 is completely abolished in presence of the ActRI inhibitor. These results show that

333 phosphorylation of Smad3 is fully mediated by the activin type I receptor as in mammals (Lee

334 and McPherron 2001; Zhu et al., 2004). The high sequence identity (90\%) of huMSTN with

335 trout MSTN together with the specificity of the signal validate the use of human MSTN in our

336 in vitro system. Our results indicate that myotubes are well responsive to huMSTN

337 stimulation and that an absence of functional MSTN signaling pathway can not explain the

338 absence of inhibitory effect of huMSTN on differentiation of trout myoblasts.

339 To determine the reasons of the lack of inhibitory effect of huMSTN on differentiation, we

340 focused on the myogenic regulatory factor MyoD given that in mammals, MSTN inhibits

341 differentiation by decreasing MyoD protein level as well as MyoD activity (Liu et al., 2001;

342 Langley et al., 2002). Our results show that huMSTN stimulation did not induce a decrease

343 of MyoD protein level nor of myogenin which is dependent on MyoD activity (Edmondson et

344 al., 1992). Therefore, our results indicate that despite an effective activation of the MSTN

345 signaling pathway, the activity of MyoD was not modified which explains the lack of

346 inhibitory effect of huMSTN treatment on differentiation. It has been shown that TGF-beta,

347 belonging to the same family of MSTN, inhibits MyoD activity through a physical interaction

348 between MyoD and Smad3 (Liu et al., 2001). Thus, we can hypothesize that at least in trout,

349 Smad3 does not interact with MyoD preventing the inhibition of differentiation of trout

350 myoblasts by a huMSTN treatment. Further studies are required to verify the reason for the

351 lack of decrease of myoD protein level in huMSTN treated cells.

352 Overall, our work show for the first time that stimulation of the MSTN pathway inhibits the

353 proliferation of trout myoblasts in vitro. This result appears in good agreement with results

354 obtained in vivo in which overexpression of follistatin, an endogenous inhibitor of MSTN,

355 induces an increase of muscle mass mainly due to hyperplasia in trout (Medeiros et al., 2009).

356 By contrast, in zebrafish overexpressing an antisense RNA of $m s t n$, the increase of muscle 
357 mass is mainly due to hypertrophy of muscle fiber (Lee et al., 2009). The discrepancy of the

358 results obtained between these species may come from the specificities of their muscle 359 growth. Indeed, trout exhibits indeterminate growth with continued hyperplasia throughout 360 much of its life cycle, whereas zebrafish exhibits determinate growth. This hypothesis is 361 reminiscent of the very interesting data showing that mstn is differentially regulated in two 362 closely related zebrafish species exhibiting either indeterminate (Danio aequipinnatus) or 363 determinate (Danio rerio) growth (Biga and Meyer 2009).

364 Another interesting result is the absence of inhibitory effect of huMSTN on the differentiation 365 of trout myoblasts by contrast to what is observed in mammals (Langley et al., 2002; Joulia et 366 al., 2003; Trendelenburg et al., 2009). This result strongly suggests that the function of 367 endogenous MSTN in trout is partly different from that of mammals. In this context it is 368 relevant to point out that the fish mstn genes are widely expressed and that numerous non369 muscle tissues express mstn as much as in the muscle (Rescan et al., 2001; Roberts and Goetz 370 2001; Amali et al., 2004; Garikipati et al., 2006; Ko et al., 2007). Moreover, we recently 371 showed that the mechanisms involved in mstn expression in trout are different from that of 372 mammals (Seiliez et al., 2011). Finally, it is surprising that upon physiological conditions, no 373 changes of mstn expression in accordance with a strong inhibitory effect of MSTN on muscle 374 growth, has been reported in trout (Rescan et al., 2001; Chauvigné et al., 2003; Martin and 375 Johnston 2005) .

376 Overall these data highlight interspecies differences in the function of MSTN. In this context, 377 the trout with an indeterminate growth, is an interesting model to better understand of the 378 mechanisms involved in muscle growth. 
380 Acosta, J., Carpio, Y., Borroto, I., Gonzalez, O. and Estrada, M.P., 2005. Myostatin gene 381 silenced by RNAi show a zebrafish giant phenotype. J Biotechnol. 119, 324-331.

382 Amali, A.A., Lin, C.J., Chen, Y.H., Wang, W.L., Gong, H.Y., Lee, C.Y., Ko, Y.L., Lu, J.K., 383 Her, G.M., Chen, T.T. and Wu, J.L., 2004. Up-regulation of muscle-specific transcription 384 factors during embryonic somitogenesis of zebrafish (Danio rerio) by knock-down of 385 myostatin-1. Dev Dyn. 229, 847-856.

386

387

388

389

390

391

392

393

394

395

396

397

398

399

400

401

402

403

404

405

406

407

408

409

410

411

412

413

414

415

416

417

418

419

420

421

Artaza, J.N., Bhasin, S., Magee, T.R., Reisz-Porszasz, S., Shen, R.Q., Groome, N.P., Fareez, M.M. and Gonzalez-Cadavid, N.F., 2005. Myostatin inhibits myogenesis and promotes adipogenesis in $\mathrm{C} 3 \mathrm{H}$ 10T(1/2) mesenchymal multipotent cells. Endocrinology 146, 35473557.

Biga, P.R. and Meyer, J., 2009. Growth hormone differentially regulates growth and growthrelated gene expression in closely related fish species. Comp Biochem Physiol A Mol Integr Physiol 154, 465-473.

Brunelli, J.P., Robison, B.D. and Thorgaard, G.H., 2001. Ancient and recent duplications of the rainbow trout Wilms' tumor gene. Genome 44, 455-462.

Chauvigné, F., Gabillard, J.C., Weil, C. and Rescan, P.Y., 2003. Effect of refeeding on IGF1, IGF2, IGF receptors, FGF2, FGF6 and myostatin mRNA expression in rainbow trout (Oncorhynchus mykiss) myotomal muscle. Gen Comp Endocrinol 132, 209-215.

Edmondson, D.G., Cheng, T.C., Cserjesi, P., Chakraborty, T. and Olson, E.N., 1992. Analysis of the myogenin promoter reveals an indirect pathway for positive autoregulation mediated by the muscle-specific enhancer factor MEF-2. Mol Cell Biol 12, 3665-3677.

Funkenstein, B. and Rebhan, Y., 2007. Expression, purification, renaturation and activation of fish myostatin expressed in Escherichia coli: facilitation of refolding and activity inhibition by myostatin prodomain. Protein Expr Purif 54, 54-65.

Gabillard, J.C., Sabin, N. and Paboeuf, G., 2010. In vitro characterization of proliferation and differentiation of trout satellite cells. Cell Tissue Res 342, 471-477.

Garikipati, D.K., Gahr, S.A., Roalson, E.H. and Rodgers, B.D., 2007. Characterization of rainbow trout myostatin-2 genes (rtMSTN-2a and $-2 b$ ): genomic organization, differential expression, and pseudogenization. Endocrinology 148, 2106-2115.

Garikipati, D.K., Gahr, S.A. and Rodgers, B.D., 2006. Identification, characterization, and quantitative expression analysis of rainbow trout myostatin-1a and myostatin- $1 \mathrm{~b}$ genes. $\mathrm{J}$ Endocrinol 190, 879-888.

Inman, G.J., Nicolás, F.J., Callahan, J.F., Harling, J.D., Gaster, L.M., Reith, A.D., Laping, N.J. and Hill, C.S., 2002. SB-431542 is a potent and specific inhibitor of transforming growth factor-beta superfamily type I activin receptor-like kinase (ALK) receptors ALK4, ALK5, and ALK7. Mol Pharmacol 62, 65-74.

Johnston, I.A., 1999. Muscle development and growth: potential implications for flesh quality in fish. Aquaculture 177, 99-115.

Joulia, D., Bernardi, H., Garandel, V., Rabenoelina, F., Vernus, B. and Cabello, G., 2003. Mechanisms involved in the inhibition of myoblast proliferation and differentiation by myostatin. Exp Cell Res. 286, 263-275.

Kerr, T., Roalson, E.H. and Rodgers, B.D., 2005. Phylogenetic analysis of the myostatin gene 
sub-family and the differential expression of a novel member in zebrafish. Evol Dev 7, 390400.

Ko, C.-F., Chiou, T.-T., Chen, T.T., Wu, J.-L., Chen, J.-C. and Lu, J.-K., 2007. Molecular cloning of myostatin gene and characterization of tissue-specific and developmental stagespecific expression of the gene in orange spotted grouper, Epinephelus coioides. Mar Biotechnol (NY) 9, 20-32.

Kocamis, H. and Killefer, J., 2002. Myostatin expression and possible functions in animal muscle growth. Domest Anim Endocrinol 23, 447-454.

Langley, B., Thomas, M., Bishop, A., Sharma, M., Gilmour, S. and Kambadur, R., 2002. Myostatin inhibits myoblast differentiation by down-regulating MyoD expression. J Biol Chem 277, 49831-49840.

Lee, C.-Y., Hu, S.-Y., Gong, H.-Y., Chen, M.H.-C., Lu, J.-K. and Wu, J.-L., 2009. Suppression of myostatin with vector-based RNA interference causes a double-muscle effect in transgenic zebrafish. Biochem Biophys Res Commun 387, 766-771.

Lee, S.J. and McPherron, A.C., 2001. Regulation of myostatin activity and muscle growth. Proc Natl Acad Sci U S A 98, 9306-9311.

Liu, D., Black, B.L. and Derynck, R., 2001. TGF-beta inhibits muscle differentiation through functional repression of myogenic transcription factors by Smad3. Genes Dev 15, 2950-2966.

Martin, C.I. and Johnston, I.A., 2005. The role of myostatin and the calcineurin-signalling pathway in regulating muscle mass in response to exercise training in the rainbow trout Oncorhynchus mykiss Walbaum. J Exp Biol 208, 2083-2090.

McFarland, D.C., Velleman, S.G., Pesall, J.E. and Liu, C., 2007. The role of myostatin in chicken (Gallus domesticus) myogenic satellite cell proliferation and differentiation. Gen Comp Endocrinol 151, 351-357.

McFarland, D.C., Velleman, S.G., Pesall, J.E. and Liu, C.N., 2006. Effect of myostatin on turkey myogenic satellite cells and embryonic myoblasts. Comp Biochem Physiol A Mol Integr Physiol 144, 501-508.

McPherron, A.C., Lawler, A.M. and Lee, S.J., 1997. Regulation of skeletal muscle mass in mice by a new TGF-beta superfamily member. Nature 387, 83-90.

Medeiros, E.F., Phelps, M.P., Fuentes, F.D. and Bradley, T.M., 2009. Overexpression of follistatin in trout stimulates increased muscling. Am J Physiol Regul Integr Comp Physiol 297, R235-R242.

Mommsen, T.P., 2001. Paradigms of growth in fish. Comparative Biochemistry and Physiology B Biochemistry \& Molecular Biology 129, 207-219.

Rescan, P.Y., Jutel, I. and Ralliere, C., 2001. Two myostatin genes are differentially expressed in myotomal muscles of the trout (Oncorhynchus mykiss). J Exp Biol 204, 3523-3529.

Roberts, S.B. and Goetz, F.W., 2001. Differential skeletal muscle expression of myostatin across teleost species, and the isolation of multiple myostatin isoforms. FEBS Lett 491, 212216.

Rodgers, B.D. and Weber, G.M., 2001. Sequence conservation among fish myostatin orthologues and the characterization of two additional cDNA clones from Morone saxatilis and Morone americana. Comp Biochem and Physiol B Biochem \& Mol Biol 129, 597-603.

Rodgers, B.D., Weber, G.M., Sullivan, C.V. and Levine, M.A., 2001. Isolation and characterization of myostatin complementary deoxyribonucleic acid clones from two 
466

commercially important fish: Oreochromis mossambicus and Morone chrysops. Endocrinology 142, 1412-1418.

Ríos, R., Carneiro, I., Arce, V.M. and Devesa, J., 2001. Myostatin regulates cell survival during C2C12 myogenesis. Biochem Biophys Res Commun 280, 561-566.

Sartori, R., Milan, G., Patron, M., Mammucari, C., Blaauw, B., Abraham, R. and Sandri, M., 2009. Smad 2 and 3 transcription factors control muscle mass in adulthood. Am J Physiol Cell Physiol 296, C1248-C1257.

Sawatari, E., Seki, R., Adachi, T., Hashimoto, H., Uji, S., Wakamatsu, Y., Nakata, T. and Kinoshita, M., 2010. Overexpression of the dominant-negative form of myostatin results in doubling of muscle-fiber number in transgenic medaka (Oryzias latipes). Comp Biochem Physiol A Mol Integr Physiol 155, 183-189.

Seiliez, I., Sabin, N. and Gabillard, J.-C., 2011. FoxO1 Is Not a Key Transcription Factor in the Regulation of myostatin (mstn-1a and mstn-1b) Gene Expression in Trout Myotubes. Am J Physiol Regul Integr Comp Physiol 301, R97-R104.

Terova, G., Bernardini, G., Binelli, G., Gornati, R. and Saroglia, M., 2006. cDNA encoding sequences for myostatin and FGF6 in sea bass (Dicentrarchus labrax, L.) and the effect of fasting and refeeding on their abundance levels. Domest Anim Endocrinol 30, 304-319.

Theil, P.K., Sorensen, I.L., Nissen, P.M. and Oksbjerg, N., 2006. Temporal expression of growth factor genes of primary porcine satellite cells during myogenesis. Animal Science Journal 77, 330-337.

Thomas, M., Langley, B., Berry, C., Sharma, M., Kirk, S., Bass, J. and Kambadur, R., 2000. Myostatin, a negative regulator of muscle growth, functions by inhibiting myoblast proliferation. J Biol Chem 275, 40235-40243.

Trendelenburg, A.U., Meyer, A., Rohner, D., Boyle, J., Hatakeyama, S. and Glass, D.J., 2009. Myostatin reduces Akt/TORC1/p70S6K signaling, inhibiting myoblast differentiation and myotube size. Am J Physiol Cell Physiol 296, C1258-C1270.

Xu, C., Wu, G., Zohar, Y. and Du, S.J., 2003. Analysis of myostatin gene structure, expression and function in zebrafish. J Exp Biol 206, 4067-4079.

Zhao, J., Crowe, D.L., Castillo, C., Wuenschell, C., Chai, Y. and Warburton, D., 2000. Smad7 is a TGF-beta-inducible attenuator of Smad2/3-mediated inhibition of embryonic lung morphogenesis. Mech Dev 93, 71-81.

Zhu, X., Topouzis, S., Liang, L.-F. and Stotish, R.L., 2004. Myostatin signaling through Smad2, Smad3 and Smad4 is regulated by the inhibitory Smad7 by a negative feedback mechanism. 


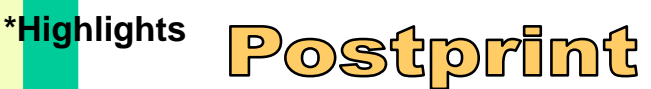

Version définitive du manuscrit publié dans / Final version of the manuscript published in : Molecular and Cellular Endocrinology 2012, 351 (2): 220-226

Myostatin inhibits proliferation but not differentiation of trout myoblasts 


\begin{tabular}{cccc}
\hline Gene & Accession Number & Forward primer & Reverse Primer \\
\hline eF1a & AF498320 & cattgacaagagaaccattga & ccttcagcttgtccagcac \\
Mstn1a & AF273035 & ccgccttcacatatgccaa & cagaacctgcgtcagatgca \\
Mstn1b & AF273036 & agtccgccttcacgcaaa & accgaaagcaaccataaaactca \\
\hline
\end{tabular}


AFigure1

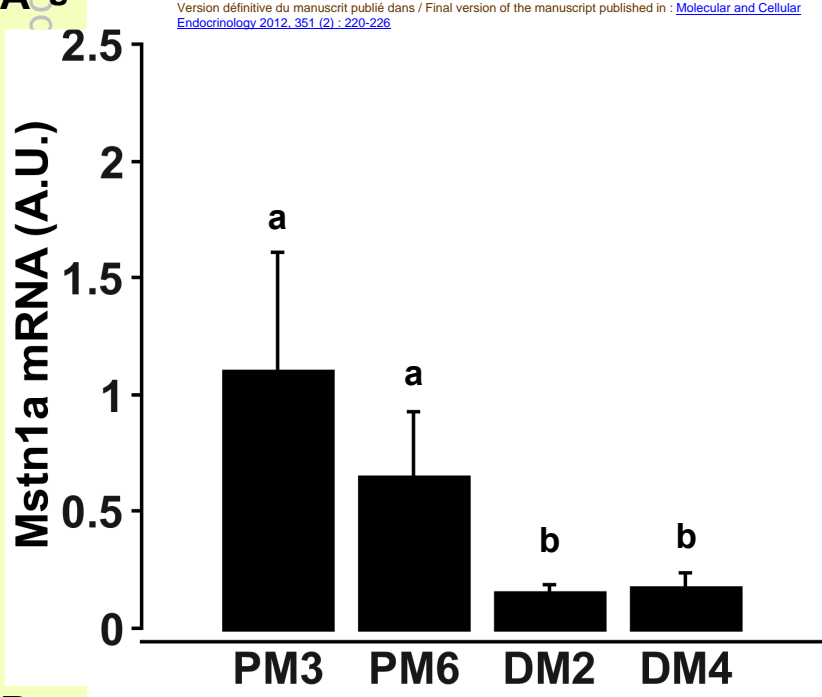

B

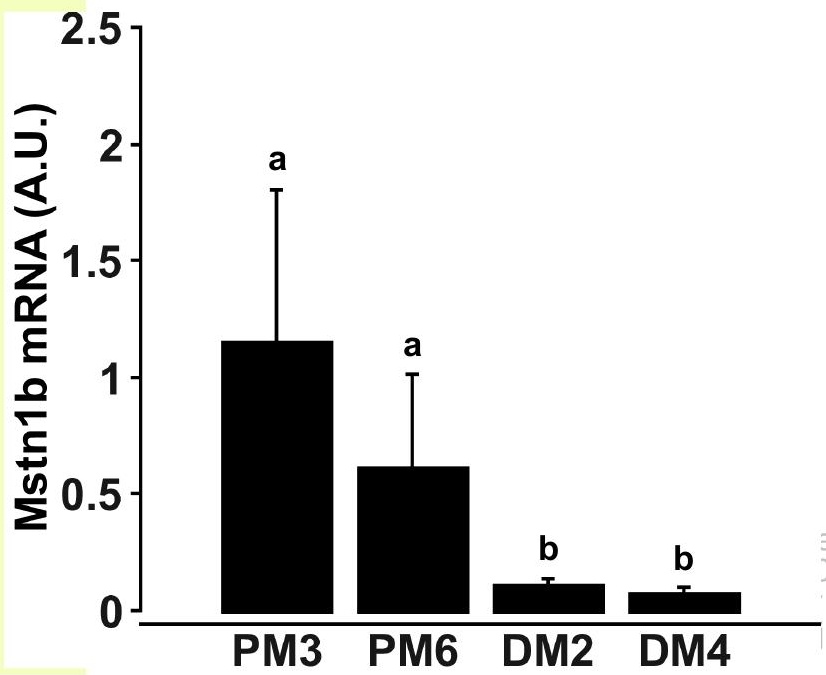




\section{Myoblasts}

MSTN

Inh

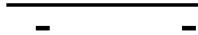

$+$

$+$

- $\quad+$

-

$+$

\section{P-Smad3}

b-actin

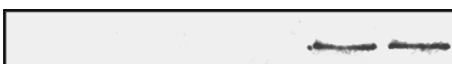

B

\section{Myotubes}

MSTN

Inh

P-Smad3

b-actin

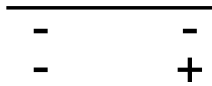

$+$

$+$

$-$

$+$

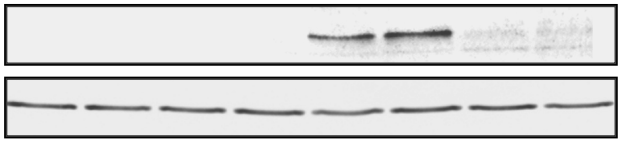

Seiliez, I., Sabin, N., Gabillard, J.-C. (2C
erentiation of trout myoblasts. Molecular differentiation of trout myoblasts. Molecular
DOI : $10.1016 / \mathrm{j}$ 
Figure3

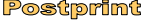

Version définitive du manuscrit publié dans / Final version of the manuscript published in : Molecular and Cellular Fndocrinalnav $7012 \quad 351(2) \cdot 720-276$

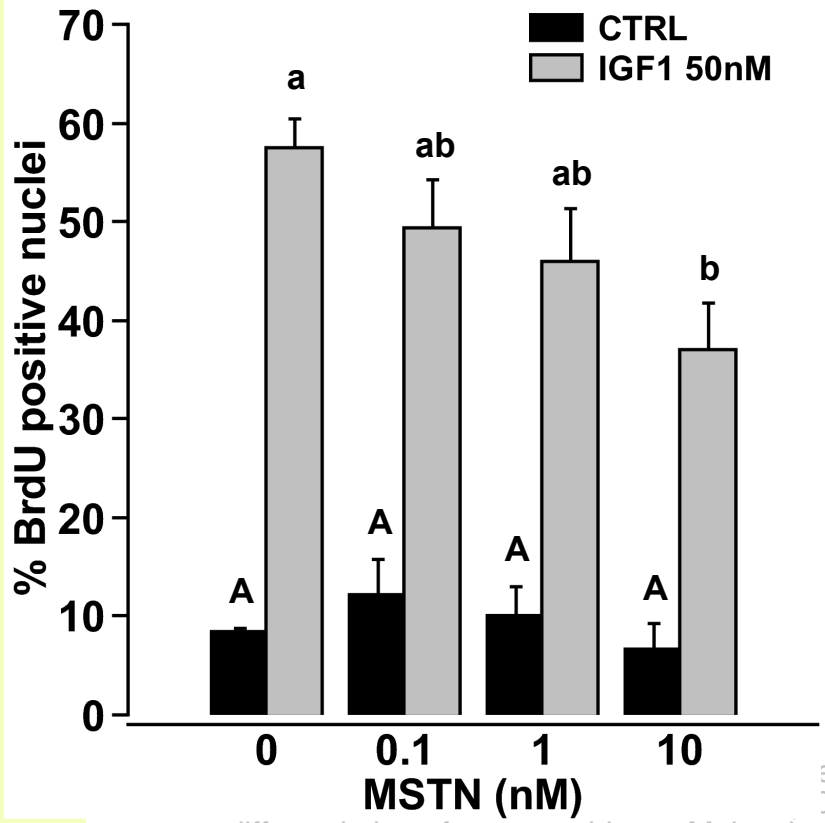

differentiation of trout myoblasts. Molecular 


\section{AFigure4}

CTRL

MSTN 100 nM
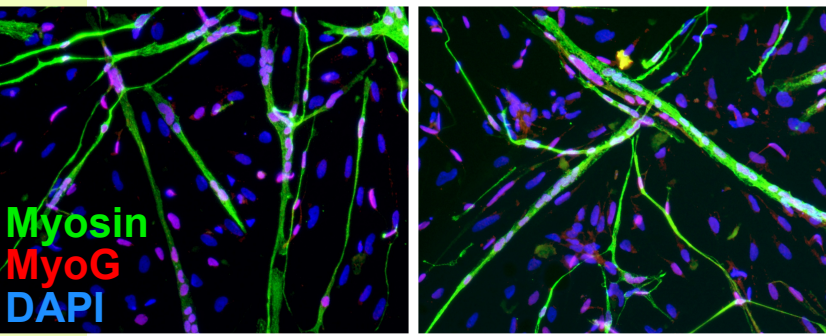

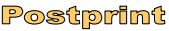

Version définitive du manuscrit publié dans / Final version of the manuscript published in : Molecular and Cellular Endocrinology 2012, 351 (2) : 220-226

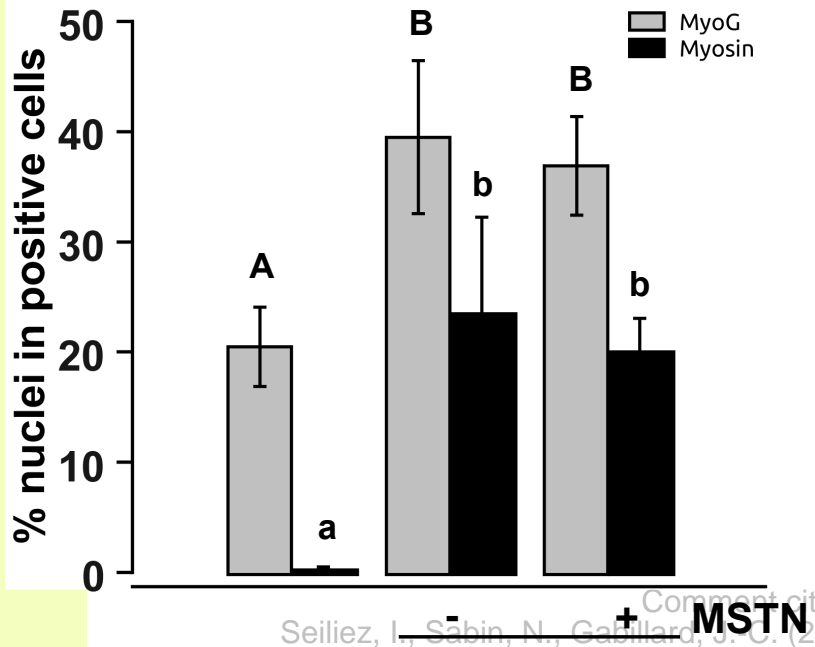




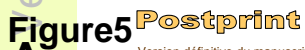

Version définitive du manuscrit publié dans / Final version of the manuscript published in : Molecular and Cellular Endocrinology $2012,351(2): 220-226$

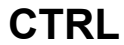

MSTN

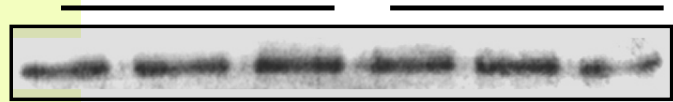

MyoD

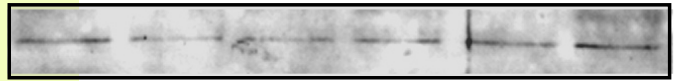

MyoG

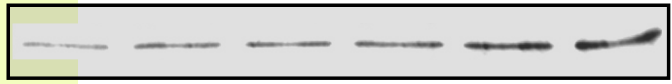

\section{Smad7}

b-actin

B

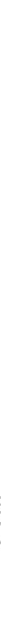

